\title{
THE UNIT OF ACCOUNT: ENFORCEABILITY UNDER AMERICAN LAW OF MAINTENANCE-OF-VALUE PROVISIONS IN INTERNATIONAL BONDS
}

A NEW device for allocating the risk of currency fuctuations in international lending was introduced this past year in bonds issued by $\operatorname{SACOR}^{1}$ a Portuguese oil company. The borrower's willingness to accept much of the risk of devaluation of its own currency, by giving investors in the various countries the option of demanding repayment in any of seventeen named European currencies, ${ }^{2}$ made it possible to obtain ten million dollars at unusually low interest rates. ${ }^{3}$ The marked success of this bond issue ${ }^{4}$-in

1. N.Y. Times, Jan. 11, 1961, p. 1, col. 6. See also id. at p. 4, col. 4. The new device employed by SACOR (Sociedade Anónima Concessionária da Refinaçao de Petróleos em Portugal) had been suggested in a study done for the Institut International d'Etudes Bancaires by Belgian banker-economist Fernand Collin. Collin, The USE of a CurRENCY of AcCount in International Loans (1958). Mr. Collin first made his proposal to revitalize the international money markets in a lecture by the same title delivered two years earlier at the Yale Law School. Address by Fernand Collin, Yale Law School, Oct. 4,1956 , on file in Yale Law Library.

2. The currencies included as repayment media were those of the countries belonging to the former European Payments Union (EPU): Austria, Belgium, Denmark, France, Germany, Greece, Iceland, Ireland, Italy, Iuxemburg, the Netherlands, Norway, Portugal, Sweden, Switzerland, Turkey, and the United Kingdom. Purchasers of the bonds were able to pay in any of six currencies: British pounds sterling, French francs, Belgian francs, Swiss francs, Dutch guilders, or German marks. SACOR Prospectus, p. 3 (1961), on file in Yale Law Library.

3. N.Y. Times, Jan. 31,1961 , p. 43 , col. 5. The borrowing was achieved through two public offerings, each one of five million dollars' worth of bonds, carrying an interest rate of 53/4\% and maturing in 1978. Id., Jan. 11, 1961, p. 4, col. 4. See also SACOR Prospectus, p. 1 (1961). This interest rate may be compared with the higher rates paid by comparable companies in other European countries. In Germany, by July, 1960, the interest rate on new issues payable in deutsche marks had risen to about $7 \%$ even from domestic borrowers. The cost of industrial bond issues in France was about 8\%. Member firms of the mechanicalindustrial group had participated in industry-wide issues at an annual cost of $8.25 \%$, which included an interest rate of $6 \%$, although the tax-free status of such issues made them particularly attractive to bond buyers. Elman, Unpublished Thesis in Yale Law Library, ch. III (1962).

The SACOR bond rate is all the more surprising when the unstable political situation in the borrower's country is considered. World attention about this time was focused on Portugal because of the pirating of one of its ships by a political foe of the Salazar regime, and there was real danger of revolution in Portugal itself. N.Y. Times, Jan. 25, 1961, p. 1 , cols. $5-8$; id. at p. 13 , cols. $1,7,8$.

4. The first offering of five million dollars was over-subscribed by $600 \%$ in the five countries in which underwriters had agreed to accept the bonds. Orders were also received from the United States, as well as from countries whose currencies were included in the repayment provision. N.Y. Times, Jan. 31, 1961, p. 43, col. 5. Even as the response to the bonds was becoming known, there was talk of additional borrowings of the same type. Id., Jan. 11, 1961, p. 1, col. 6. Announcement of similar bond issues is expected to follow shortly, as the system becomes more widely known. 
capital markets which are becoming increasingly conducive to foreign portfolio investments "-should encourage further use of SACOR type bonds. These bonds would be even more attractive to investors if the United States dollar were among the repayment currencies, ${ }^{6}$ but its inclusion is unlikely in view of the problematical enforcement in American courts of stabilization clauses, because of the Joint (Gold Clause) Resolution of June 5, 1933.7 The SACOR bonds, perhaps distinguishable from other kinds of maintenance-ofvalue clauses used in the past, offer a means of determining the reach of the Resolution and re-evaluating its validity today.

In addition to the usual commercial risks of lending, ${ }^{8}$ transactions between a borrower and investor of different countries include the monetary risk of possible changes in the value of the borrower's currency relative to other currencies, such as devaluation of the borrower's currency. ${ }^{9}$ Obligations are

5. United Nations, International Flow of Prrvate Capital 1956-1958, at 50 (1959).

6. Because of its relative stability and strength, the United States dollar today is the currency most frequently stipulated in international obligations involving a single repayment currency, in other words, in the majority of all foreign investment contracts. Since World War II, the dollar has grown in importance as a world currency, and it is sought in foreign exchange centers as one of the "hardest" currencies. FEDERAL RESERVE BANK OF NEW YoRK, The New York Foreign Exchange Market 7-8 (1960).

7. 48 Stat. 112 (1933), 31 U.S.C. 463 (1958).

8. Political risks of foreign investment-expropriation, war, discriminatory treatmentwill not be considered in this Note, although it should be recognized that the decision to devalue or revalue is itself a political, as well as an economic, determination. Despite the fact that the frequency and extent of currency devaluations and depreciations even since the end of World War II should be sufficient evidence to indicate that the problem cannot be minimized or disregarded, it is possible that monetary risks involved in international trade and investment do not receive the consideration necessary from the standpoint of the parties involved. See Strong, Minimizing Monetary Risks in Foreign Trade, 1959 U. ILI. L.F. 355, 357.

9. In accordance with normal financial usage, there will be taken here:

as the essential criterion of what is an international loan, the fact of issue in a country or countries other than that of the borrower. The fact that bonds issued in the country of the debtor have been acquired by residents in another country does not of course confer on such loans the character of an international loan.

League of Nations, Report of the Committee for the Study of International Loan Contracts 6-7 (1939). Because the economic life of each of the parties to such an agreement is based upon a different standard, or currency, the relationship between the two standards is of crucial importance. In this regard, however, it is important to distinguish between depreciation of a currency, an economic phenomenon, and devaluation of a currency, a legislative act altering the ratio between the monetary unit and other currencies or gold. Although the investor will be affected adversely in either event, the risk of depreciation of the currency's purchasing power (in other words, inflation) is common to both domestic and foreign investors. It is the added risk of loss of currency-purchasing power through devaluation that the investor in foreign securities must face, in the sense that he may receive in repayment of the loan an amount that will not equal the amount of his own currency he lent originally, even before taking into account the purchasing power of currency. See Nussbaum, Money in the Law-National and International 171-80 (1950 ed.) [hereinafter cited as MONEY IN THE LAw]. 
ordinarily stated as fixed amounts of a given currency. If repayment is to be made in the borrower's currency, lowering of the official exchange rate of that currency without a corresponding change in the bondholder's currency will result in the investor receiving less face value of his own currency than he lent. Bonds to be offered to investors abroad, therefore, may contain clauses designed to maintain the stability of the debt by reference to an extrinsic measure of value. ${ }^{10}$ For instance, a stabilization clause may require repayment in some other currency, often the investor's, which it is believed will prove stronger than that of the borrower. Even greater protection is afforded the bondholder if he may choose from among a number of different currencies at the time of repayment, ${ }^{11}$ since he need make no predictions but can simply choose that currency which then has the greatest value. Moreover, by expressing the terms of repayment in the currency of many capital markets, the multilateralization of borrowing is promoted, since a single bond issue can be floated simultaneously in several countries. ${ }^{12}$ The particular variation of the stabilization clause employed in the SACOR bonds represents a new method of achieving both objectives, the protection of investors and the "international mobilization of savings."13

The stabilization clause in SACOR bonds expresses the substance of the obligation in terms of an artificial currency, the unit of account or measurement_-"unitacct"14_being originally the amount of each of the national cur-

10. Generically such protective devices may be called "maintenance-of-value clauses," "stability clauses," or simply "value clauses." Specific examples include gold clauses, multiple currency clauses, commodity clauses, index clauses, and the new unit of account provision. See generally Nussbaum, Multiple Currency and Index Clauses, 84 U. PA. L. Rev. 569 (1936).

11. For the distinctions between various types of currency clauses, see MONEY IN THE Law 388-89. See also Delaume, Gold and Currency Clanses in Contemporary Intcrnational Loans, 9 AMr. J. Comp. L. 199, 210 (1960) ; MANN, The Legal Aspect of Money 113 (1953 ed.). The term "multiple currency clause" will here be confined to the option $d e$ change form, in which a definite amount is provided in terms of each currency involved, independent of the reciprocal fluctuations of the rate of exchange.

A thorough analysis of the economic, social, and political differences between multiple currency clauses and gold clauses is presented in Nussbaum, supra note 10, at 576-77. A further advantage of the multiple currency clause is the pragmatic fact that it involves less likelihood of default than is the case with gold clause bonds, due in part to a greater willingness to repay foreign lenders set amounts in their own currency than amounts set by a seemingly artificial gold standard and in part to the greater likelihood of depreciation of the alternative currencies as well as of the currency of the borrower. LeaGUE of Nations, op. cit. supra note 9, at 28-29.

12. The opportunity to tap numerous money markets at the same time is referred to as breaking the "capital barrier" which considerably restricts borrowing across country borders. N.Y. Times, Jan. 11, 1961, p. 1, col. 6 . Protective clauses facilitating such borrowing prior to 1931 were one indication of the high development of financial technique in international finance. Money In the Law 387. See League of Nations, op. cit. supra note 9 , at 29.

13. UNITED NATIONs, op. cit. supra note 5 , at 50 .

14. The term "unitacct" is offered as an alternative denomination for the unit of account device in general. Collin's specific proposal was based upon the "Epunit," note 
rencies required to equal the chosen figure of 0.88867088 grams of fine gold.15 Unless all of the stated currencies are devalued or revalued, the investor may demand interest and principal payments as they become due in any of the currencies in an amount at that time equal to the original unit. ${ }^{16}$ Because the fixed element in the obligation is the number of unitaccts, ${ }^{17}$ fluctuations in the value of currencies ${ }^{18}$ are automatically balanced by changes in the amount of currency necessary to equal the unit. Thus, if Portuguese currency were to be devalued by $50 \%$, the investor of one thousand escudos would receive, assuming he chose repayment in that currency, two thousand escudos. In case of devaluation or revaluation of every one of the currencies in the same direction, the original unit is to be alterated to the same extent as the currency which has been least altered in terms of gold value. ${ }^{19}$ If some of the currencies revalue and some devalue, the value of the unit will be reduced in the same proportion as the decrease in value of the currency which has been devalued least. For example, repayment would be on the basis of an amount of any of the currencies equal to 0.66650316 grams of gold if one of the currencies were devalued by only $25 \%$ while all others were devalued to a greater degree.

The protection afforded the investor is accompanied by a corresponding assumption of risk by the borrower. ${ }^{20}$ Where the borrower's currency is de-

15 infra, an expression which he termed a "not particularly pleasant sounding name." CoLLis, op. cit. supra note 1, at 19. Repeated calls for a less unappealing name produced several suggestions, among them "European pound," "European dollar," "dollar banco," "European franc," and "European unit of account." Proceedings of the Technical Committee for the Study of Problems Relating to an International Epunit Loan, Institut International d'Etudes Bancaires, Brussels, May 2-3, 1957.

15. The figure was chosen because of its familiarity through use as the unit of the former European Payments Union, termed the Epunit, which in turn is the equivalent of one United States dollar at the current value of thirty-five dollars per ounce. N.Y. Times, Jan. 11, 1961, p. 4, col. 4. See Colurn, op. cit. supra note 1, at 19-23.

16. SACOR Prospectus, pp. 2-3 (1961). See also ColLIN, op. cit. supra note 1, at 20-21.

17. Each bond issue is stated to be of five million Epunits, and the bonds themselves are expressed in denominations of 250 or 1000 units. SACOR Prospectus, p. 2 (1961).

18. The unitacct takes account of all official changes of value (devaluation or revaluation) of a particular currency, but unofficial changes (depreciation or appreciation) do not affect the amount of currency which may be demanded as the equivalent of the unit. See note 9 supra. In a time when free convertibility of currencies prevails, however, protection against official exchange rate changes is sufficient for the investor since governments have obligated themselves to buy and sell foreign currencies at the official rate. Even if there should come a time when currencies are not freely convertible, a device such as that employed in the SACOR bonds allows the investor to select repayment in the currency whose official rate varies least from the unofficial rate.

19. As originally proposed, the provision for this minimum flexibility in the obligation consisted of altering the unit in accordance with changes in value of the Epunit itself, which changes were limited to the extent of changes in the currency whose parity had been modified least. CoLLIN, op. cit. supra note 1, at 19. With the EPU dissolved, it was necessary to change this term to allow alteration when the national authorities of each country have officially devalued or revalued. SACOR Prospectus, p. 3 (1961).

20. See N.Y. Times, Jan. 11, 1961, p. 4, col. 4. In this limited sense, the unitacct may be regarded as only a risk-shifting device. Its value, however, arises from the multilateralization of the borrowing and in a form preferable to that of the multiple currency clause proper. 
valued, the amount in that currency necessary to equal the unit is increased to the extent that any one of the other currencies remains more stable. Stability of the debt is achieved, however, at a minimum risk to the borrower. As long as there is no change in the value of his own currency, the borrower will not be adversely affected by a change in the exchange value of any of the currencies. In this case the obligation is the equivalent of a loan in the borrower's currency, since the basic unit is not affected by revaluation of a single currency - or even of all but one of the currencies of reference. No investor in SACOR bonds could have profited from the German revaluation in 1961,21 for example, because a smaller number of deutsche marks would be required to equal the original unit if repayment were demanded in that currency. ${ }^{22}$ This situation is to be contrasted with the operation of traditional multiple currency clauses, which permit the investor to demand repayment in a fixed amount of any of the listed currencies. He is able to profit from revaluation of a single currency by demanding the fixed number of units listed in that currency, which the debtor must purchase at a higher price. ${ }^{23}$ The traditional multiple currency clause, besides thus imposing an additional burden upon the individual borrower, increases pressure upon a strong currency already likely to be in short supply. ${ }^{24}$ The tendency to stipulate strong currencies in single currency repayment obligations has the same effect. By giving the bondholder the same value regardless of which currency he selects, the unitacct levels fluctuations in multinational obligations and has a neutral effect upon the demand for particular currencies.

In return for assuming the risk of devaluation, the borrower is able to attract foreign capital without having to pay a risk premium that produces an interest rate so high that this source of funds ceases to be worthwhile to him. ${ }^{25}$ The investor, for his part, should find that with the currency risk disincentive largely removed, foreign and domestic opportunities are equally attractive at

21. The par rate for German currency was changed from 4.20 to 4.0 deutsche marks per United States dollar on March 5, 1961. International Monetary Fund, International Financial Statistics, April 1962, p. 123.

22. As part of the cost of protection against devaluations, the investor forgoes the right to profit from revaluations of individual currencies. To the extent that he might have made investments providing repayment in the currency which subsequently revalues, he is relatively disadvantaged by having invested in unitacct bonds.

23. A misleading statement in the newspaper article announcing the SACOR bond issue illustrates the distinction between a unitacct provision and a multiple currency clause. It is the practical effect of the latter, rather than, as stated, the former, that "the bond buyer has automatically invested in the 'strongest' . . currency, present and future." N.Y. Times, Jan. 11, 1961, p. 4, col. 4. In the SACOR bonds, on the other hand, emphasis is upon the stablest currency, and revaluations of strong currencies are not taken into account unless all currencies revalue. See also note 11 supra.

24. See Collin, op. cit. supra note 1, at 21-22; Money IN THE Law 390.

25. If the investor, for example, were required to accept repayment in the borrower's currency, which he regarded as likely to devalue, the interest rate which he would demand might well be so high as to prevent conclusion of the loan contract. See text at note 29 infra. 
similar rates of return. ${ }^{26}$ Moreover, bonds with multiple currency provisions are more readily exchangeable in foreign capital markets, thus increasing the stability and attractiveness of the security:

It [the multicurrency option] widens the market for a loan during the whole of its lifetime and tends to keep up the price. It is often easier to negotiate internationally [sic] securities which are expressed in the currency of each market concerned. ${ }^{27}$

An additional feature of the unitacct provision is the possibility it offers of creating a positive incentive to attract investment. Although the reduction in interest rate in unitacct obligations theoretically should equal the cost of the increased risk shifted to the borrower, the actual interest rate will be affected by differing degrees of optimism in the parties' calculations of future developments in the exchange rate of the borrower's currency. ${ }^{28}$ If the investor demands a higher interest rate for bearing the risk of devaluation than the borrower thinks the risk is worth, ${ }^{29}$ the borrower may find it advantageous to assume the risk himself. For example, if the domestic rate in the investor"s country is $5 \%$, he may demand $8 \%$ (postulating a premium of $3 \%$ ) from foreign borrowers to cover the risk of devaluation of the other currency. The borrower, on the other hand, may calculate the added risk to be worth only $2 \%$; by assuming the risk of devaluation of his own currency, he is able to effect a saving of $1 \%$. He may then offer part of this saving to the investor as an inducement to purchase the particular bonds, as long as he can keep his own costs below the domestic interest rate in the borrowing country. Assuming

26. The motives prompting investors to purchase foreign securities were stated succinctly, if deceptively, in a recent report by the Organization for European Economic Cooperation:

Such securities will be purchased if the rate of return or the chance of capital gains which they promise, when discounted for all the attendant risks, are higher than the investor believes it is possible to obtain on American securities.

Organization for European Economic Cooperation, Private United States InvestMENT IN Europe AND THE OVERSEAS TeRritories 22 (1954). Of course, any real difference between returns on domestic and foreign securities remaining after all attendant risks have been discounted will disappear as investment shifts to the more profitable area, until the point is reached at which foreign opportunities are no more, but no less, attractive than domestic opportunities. Differential rates are able to exist because the "attendant risks" in the case of foreign lending include lack of information, reluctance to enter new areas, and fear of "foreign" contracts in general. See text at note 28 infra.

27. League of Nations, op. cit. supra note 9, at 29. See UnITEd Nations, op. cit. supra note 5, at 9-10; Bloomfield, Capital Imports and American Balance of Payments, 1934-1939, at 122 (1950).

28. Compare the discussion of "structural and psychological frictions" involved in interest rate levels in Machlup, The Theory of Foreign Exchanges, in READINGS IN THE Theory of International Trade 15 (1950).

29. A tendency to think more highly of one's own currency than of a foreign currency may lead to the likelihood that the borrower will believe the risk of devaluation of his currency is lower than the investor's estimate. 
a rate of $7 \mathrm{x} / 2 \%$ in that country, ${ }^{30}$ the bargaining range for the parties will be between $5 \%$ and $5 \mathrm{r} / 2 \%$, with $2 \%$ added risk being assumed by the borrower. ${ }^{31}$ Although it may not be possible precisely to assign values to specific risk elements, the parties will necessarily weigh the risks of the transaction in this manner. And, because the outflow of private capital is often sensitive to interest rate movements, even a slight increase in the interest rate differential between domestic and foreign lending may induce a substantial increase in the more attractive one. ${ }^{32}$

Authorities in the countries in which the SACOR bonds were offered have indicated that the unitacct provisions would be valid under their respective laws. ${ }^{33}$ The same result should obtain under American law with the obligation as presently stated in the SACOR bonds. But if the bonds had included the United States dollar among the repayment currencies, enforceability of the maintenance-of-value clause in American courts would be doubtful, because of the Joint Resolution of June $5,1933,{ }^{34}$ which declares provisions for payment

30. The higher rate of $7 \frac{\pi}{2} \%$ is postulated in the borrowing country because presumably funds are less readily available than in the relatively capital-rich lending country.

31. From the standpoint of the individual borrower, the function of foreign investment may be simply stated: "[W]ishing to carry out a capital project, [he] looks for capital abroad when he can get it on terms more favorable than in his own country." ORGANIZATION for European Economic Cooperation, Report on International Investment 31 (1950). For an extensive mathematical analysis of what change must be expected in the foreign exchange rate in order to eliminate the incentive to borrow abroad, given a certain interest rate differential, see Bale, On The Exchange Risk Involved in Borrowing Abroad, $27 \mathrm{C}_{A N}$. J. Econ. \& PoL. Scr. 97 (1961).

32. Comimittee for Economic Developarent, The International. Position of the Doldar 42 (1961). See Commisston of Inguiry into National Policy in InTernational Economic Relations, International Economic Relations 44 (1934); United Nations, op. cit. supra note 5, at 9-10. But cf. Carrold, Prdvate Investadents Abroad 32 (1954).

33. Member banks of the Institut in the various European countries sent negative replies to a questionnaire asking, "Does your country's legislation or jurisprudence prohibit the use of a unit of account in international contracts, even if it offers an implicit exchange guarantee?" Recapitulation of Questionnaire, attached to Proceedings of the Technical Committee for the Study of Problems Relating to an International Epunit Loan, Institut International d'Etudes Bancaires, Brussels, May 2-3, 1957. In addition, specific authorization was received from the exchange authorities of the respective countries of sale where necessary with respect to the SACOR bond issue itself.

34. 48 Stat. 112 (1933), 31 U.S.C. § 463 (1958) :

To assure uniform value to the coins and currencies of the United States.

Whereas the holding of or dealing in gold affect the public interest, and are therefore subject to proper regulation and restriction; and

Whereas the existing emergency has disclosed that provisions of obligations which purport to give the obligee a right to require payment in gold or a particular kind of coin or currency of the United States, or in an amount in money of the United States measured thereby, obstruct the power of the Congress to regulate the value of the money of the United States, and are inconsistent with the declared policy of the Congress to maintain at all times the equal power of every dollar, coined or issued by the United States, in the markets and in the payment of debts. Now, therefore, be it

Resolved by the Senate and House of Representatives of the United States of 
"in gold ... or in an amount of money of the United States measured thereby" to be against public policy. The statute, which provides that the obligation is not void but rather dischargeable "dollar for dollar, in any coin or currency which at the time of payment is legal tender," was upheld in 1935 as constitutional with respect to private obligations in Norman v. Baltimore \& O.R.R. ${ }^{35}$ Four years later, in Guaranty Trust Co. v. Henwood, ${ }^{36}$ the Supreme Court had before it a traditional multiple currency clause in bonds with repayment to be in "gold coin of the United States" or in fixed amounts of English pounds

America in Congress assembled, That (a) every provision contained in or made with respect to any obligation which purports to give the obligee a right to require payment in gold or a particular kind of coin or currency, or in an amount in money of the United States measured thereby, is declared to be against public policy; and to such provision shall be contained in or made with respect to any obligation hereafter incurred. Every obligation, heretofore or hereafter incurred, whether or not any such provision is contained therein or made with respect thereto, shall be discharged upon payment, dollar for dollar, in any coin or currency which at the time of payment is legal tender for public and private debts. Any such provision contained in any law authorizing obligations to be issued by or under authority of the United States, is hereby repealed, but the repeal of any such provision shall not invalidate any other provision or authority contained in such law.

(b) As used in this resolution, the term "obligation" means an obligation (including every obligation of and to the United States, excepting currency) payable in money of the United States; and the term "coin or currency" means coin or currency of the United States, including Federal Reserve notes and circulating notes of Federal Reserve banks and national banking associations.

Conflicts-of-laws problems will not be discussed in the analysis of United States law which follows. It has been suggested that parties to multiple currency or unitacct obligations stipulate that the law of another country apply, and indeed this was attempted in the recent bond issue discussed at note 92 infra. See Delaume, supra note 11, at 214. Although courts may honor an expressed or implied intent of the parties with regard to this issue, MoNEx IN THE LAW 415, the Supreme Court has interpreted the Joint Resolution to be a matter of prevailing public policy which will prevent enforcement of such obligations in this forum, regardless of the controlling substantive law of the contract. See Bethlehem Steel Co. v. Zurich Gen'1 Acc. \& Liab. Ins. Co., 307 U.S. 265 (1939). The New York Court of Appeals used even stronger language in announcing the state of the lex fori. Compania de Inversiones Internacionales v. Industrial Mortgage Bank, 269 N.Y. 22, 31-32, 198 N.E. 617, 621 (1935), cert. denied, 297 U.S. 705 (1936).

35. 294 U.S. 240 (1935). Three cases decided together on February 18, 1935, constitute the so-called "Gold Clause Cases," dealing with the Joint Resolution. The major issue in the cases was not interpretation of the clauses but determination of whether Congress had the power to invalidate existing contractual provisions. Perry v. United States, 294 U.S. 330 (1935), held the Joint Resolution unconstitutional insofar as it abrogated gold clauses in Government obligations, but there was no resultant benefit to the plaintiff bondholder. The Supreme Court held that no damages could be awarded, on the theory that no loss was shown in terms of purchasing power of the legal tender "equivalent" of the gold given by the Government. See text at notes 74-75 infra. Nortz v. United States, 294 U.S. 317 (1935), reached a similar result with regard to currency in the form of gold certificates which were requisitioned prior to the date of devaluation and thus were held to be equal to the former value of the gold in terms of dollars. An exhaustive list of literature regarding gold clause abrogation may be found in MONEX IN THE LAW 283 n.17, 414 n.1.

36. 307 U.S. 247 (1939). 
or French francs or any of several other currencies. Although the language of the Resolution might have been interpreted as invalidating the gold clause but leaving unaffected the alternative provisions, ${ }^{37}$ the Supreme Court held otherwise, basing its decision on the purposes of the obligation and of the legislation: "In purpose, pattern and, as shown here, in result, the multiple currency provision is identical with the practice Congress declared to be against public policy, and it furthers a mischief which the Resolution was enacted to end." 38 The domestic defendants were permitted to satisfy their obligation by paying in United States legal tender the number of dollars equal to the gold dollars specified, although the creditors, also United States citizens, were seeking the dollar value of the alternative foreign currency they had chosen. In the companion case of Bethlehem Steel Co. v. Zurich Gen'l Acc. \& Liab. Ins. Co. ${ }^{39}$ the foreign citizenship of the bondholders did not preclude a similar application of the Resolution. The results in these two multiple currency cases were thought to follow from the Norman case, ${ }^{40}$ but since the economic position of each party in an international transaction is determined by reference to more than one currency, $\mathbf{4 1}$ it is questionable whether a government's attitude toward protective clauses in domestic transactions can reasonably be extended to international multiple-currency transactions.

The Joint Resolution, only one of many emergency actions taken during the years 1933-1934 to deal with the currency crisis of the country, ${ }^{42}$ was designed

37. Prior to the Guaranty case, every decision regarding multiple currency clauses in federal and state courts had held them valid under the Joint Resolution. Anglo-Continentale Treuhand, A.G. v. St. Louis Southwestern Ry., 81 F.2d 11 (2d Cir. 1936) (L. Hand, J.), cert. denied, 298 U.S. 655 (1936) ; McAdoo v. Southern Pac. Co., 10 F. Supp. 953 (N.D. Cal. 1935), rev'd for lack of jurisdiction, 82 F.2d 121 (9th Cir. 1936) ; Zurich Gen'l Acc. \& Liab. Ins. Co. v. Bethlehem Steel Co., 279 N.Y. 495, 18 N.E. $2 d 673$ (1939), rev'd (in companion case to Guaranty) sub nom. Bethlehem Steel Co. v. Zurich Gen'l Acc. \& Liab. Ins. Co., 307 U.S. 265 (1939). The Supreme Court had denied certiorari in the only case of this nature appealed to it. Anglo-Continentale Treuhand, A.G. v. St. Louis Southwestern Ry., supra.

Commentators both before and after the Guaranty Trust decision regarded the approach indicated here in the text as the logical approach to a series of optional terms only one of which was dealt with by the statute-in other words, the gold coin provision would be converted to a legal tender amount following the Norman precedent, but remain as only one of the currencies in which repayment could be demanded by the investor. See MoNEY IN THE LAw 435-36 n.9; Nussbaum, Multiple Currency and Index Clauses, 84 U. PA. L. REv. 569, 571 (1936); Weigert, The Abrogation of Gold-Clauses in International Loans and the Conflict of Laws, in N.Y. Univ. School of Law, Contemporary Law Pamphlets, Series 4, No. 4, at 33 (1940).

38. 307 U.S. 247, 257 (1939). But see Nussbaum, supra note 10, at 576.

39. 307 U.S. 265 (1939).

40. See text at notes $54-55,72-73$ infra.

41. See text at notes 78-79 infra.

42. See discussion of this crisis by the Supreme Court in Norman v. Baltimore \& O. R. R., 294 U.S. 240, 295-97 (1935). But see MONEY IN THE LAW 282, for the analogous effect of the Joint Resolution itseif :

In legal history there is probably no other enactment of a purely private-law character which has engendered financial dislocations to such a vast extent and which though national in itself has caused such severe repercussions in the international field. 
to relieve existing burdens on debtors, but its prohibition of provisions for payment in gold, or in amounts of United States money measured thereby, extended into the future as well. ${ }^{43}$ Obligations of this type were declared by the preamble of the statute to "obstruct the power of the Congress to regulate the value of the money of the United States." The bonds involved in Norman called for the payment of "gold coin of the United States of America or of equal to the standard of weight and fineness existing on February 1, 1930 [the date of issuance of the bonds]."44 If the provisions had been construed literally, as calling for actual payment in gold coin, they would have been directly opposed, of course, to the stated congressional policy of regulating the currency through the removal of gold from circulation. ${ }^{45}$ Construed as gold value clauses, establishing a fixed measure of value by reference to gold, the provisions were held by the Court in Norman to be similarly within the prohibition of the Joint Resolution. ${ }^{46}$ In so holding, the majority focused upon Congress' power to provide for orderly devaluation of the currency and its intent to protect parties against disastrous effects therefrom:

43. See text of Joint Resolution, supra note 34 ("no such provision shall be contained in or made with respect to any obligation hereafter incurred").

44. 294 U.S. at 293.

45. This measure had been taken earlier, in May, 1933, when the "run" on banks by parties seeking to redeem currency in actual gold had threatened to exhaust United States supplies of the money standard. Contracts for the delivery of gold as a commodity, such as for jewelry or industrial purposes, were not affected, and the parties remained subject to any obligations of this sort. Arguments that the common gold clauses constituted commodity contracts were properly dismissed in summary fashion, in recognition of the obvious intention of the parties to create a money obligation. See Holyoke Water Power Co. v. American Writing Paper Co., 300 U.S. 324, 335 (1937), holding a lease convenant dischargeable dollar for dollar despite words in the contract itself classifying the gold payments as delivery of a commodity.

46. 294 U.S. at 314-15. The distinction between gold coin and gold value clauses had been introduced in this country by Professor Nussbaum, whose interpretation was adopted by the Supreme Court in preference to several other possible theories, including invalidation of the entire obligation. MONEY IN THE LAW $248 \mathrm{n} .2$. By this approach, the gold coin clauses included an implied promise to pay the equivalent value of the gold if gold coin were not available at the time of repayment. Id. at 248 .

Despite the language of the statute as interpreted by the Supreme Court, the distinction between gold coin provisions and gold value provisions is not clear in congressional discussion. In two of the three instances that the language of the bill is quoted in debate, only the prohibition against payment in actual gold is mentioned and the additional phrase "or in an amount in money of the United States measured thereby" is omitted. See 77 CoNG. REc. 4921-22 (1933). See also remarks by the sponsor of the bill in the House of Representatives:

Under the proclamation of the President the Government has assumed complete control of the Nation's supply of gold. This has been done to prevent hoarding and to prevent the withdrawal of gold by citizens of foreign governments.

This resolution ratifies and reaffirms the former action of Congress and everything that has been done pursuant to the authority conferred upon the President.

This resolution declares that contracts requiring the discharge of obligations solely by paynent in gold are contrary to public policy ....

77 Cong. Rec. 4528 (1933) (Rep. Steagall) (emphasis added). 
It requires no acute analysis or profound economic inquiry to disclose the dislocation of the domestic economy which would be caused by such a disparity of conditions in which, it is insisted, those debtors under gold clauses should be required to pay one dollar and sixty-nine cents in currency while respectively receiving their taxes, rates, charges and prices on the basis of one dollar of that currency. ${ }^{47}$

Although a large part of what brief discussion did take place regarding this legislation in Congress ${ }^{48}$ was concerned with the availability of less than four billion dollars in gold to satisfy a potential demand for one hundred billion dollars in gold dollar obligations, ${ }^{49}$ the magnitude of the burden upon debtors if forced to pay sixty per cent more dollars than they had borrowed was also emphasized. ${ }^{50}$ The force of the latter consideration was increased by the fact that gold coin clauses in earlier years had become standard provisions and were inserted almost automatically in all kinds of contracts, from corporate bonds to individual farm mortgages. ${ }^{51}$ Because the parties in many instances had not fully considered the import of the obligation in the event of devaluation or of abandonment of the gold standard, enforcement would indeed have inflicted unbargained-for losses on numerous debtors. ${ }^{52}$

47. 294 U.S. at 315-16. Because Congress might otherwise be deterred from devaluating the currency through concern for parties obligated to pay debts at the old rate, the necessary and proper extension of the currency power of Congress, U.S. CoNsT. art. I, § 8, cl. 18, authorized the action of invalidating such contracts to lessen the impact of devaluation. See Nussbaum, Comparative and International Aspects of American Gold Clause Abrogation, 44 Y ALE L.J. 53, 59-60 (1934).

48. The Joint Resolution was introduced, passed, and signed within ten days, following three hours of debate in each House and no hearings. The views of the minority were expressed as final debate opened:

It was only introduced last Friday afternoon, sent to the Printer, and reported by the Banking and Currency Committee Saturday morning without any consideration worthy of the name, and it is called up for passage in the House today, the next legislative day after it was reported, and only 2 legislative days after it was introduced. It is a travesty to attempt to consider legislation of this importance in this way. Everyone knows it cannot be considered seriously or adequately debated under such circumstances. This is no ordinary piece of legislation. It would be hard to overestimate its importance .... It is ridiculous to bring up in this way legislation which the gentleman from Mississippi says is the most far-reaching resolution that ever faced the human race.

77 Cong. Rec. 4520 (1933) (remarks of Rep. Mapes).

49. E.g., 77 CoNG. REc. 4528-29, 4531, 4534 (1933). But see the estimates accepted by the Supreme Court in Norman v. Baltimore \& O. R.R. 294 U.S. 240, 313 (1935).

50. E.g., 77 ConG. Rec. 4521,4526 (1933). See text at note 48 supra.

In this regard, the effect of the Joint Resolution in rendering inoperative gold coin and gold value clauses was characterized as "a virtual release of debts ... on the largest scale ever recorded." Nussbaum, Comparative and International Aspects of American Gold Clause Abrogation, 44 YALE L.J. 53, 58 (1934).

51. Id. at 60 ("a matter of custom since the beginning of the Republic") ; Nussbaum, International Legal Effects of Dollar Depreciation, 2 U. CHI. L. REv. 291 (1935).

52. See Money in the Law 285. But see Dunne, Monetary Decisions of the SUPREME CoURT 89 (1960). 
When faced in Guaranty Trust Co. v. Henwood ${ }^{53}$ with domestic bonds in which a gold clause was included among multiple currency provisions, the Supreme Court, in a five-four decision, considered invalidation a necessary extension of the debtor-protection approach of Norman:

The mischief Congress intended to end will not end if the multiple currency provision of these bonds is held to be unaffected by the Resolution. Congress sought to outlaw all contractual provisions which require debtors, who have bound themselves to pay United States dollars, to pay a greater number of dollars than promised. ${ }^{54}$

Mr. Justice Stone, a member of the majority in Norman, dissented, criticizing the majority's reliance on the "mischief"5s which led to the passage of the Joint Resolution as a guide to determining what situations were covered by its terms. ${ }^{56} \mathrm{He}$ argued that neither the language nor the legislative history of the Joint Resolution afforded any basis for finding a prohibition against value clauses in general or for assuming that:

[T] he resolution was aimed at anything other than provisions calling for payment in gold value or gold dollars or their equivalent, which Congress explicitly named and described as the evil to be remedied, both in the Joint Resolution and in the committee reports attending its adoption. ${ }^{57}$

Although the majority opinion broadly interpreted and emphasized the purpose of the Resolution, they did, in fact, relate the bond provisions to the statute being construed. The "hook" presence of the gold coin provision as one of the alternatives for repayment, which fact permitted characterization of the obligation as a "multiple currency provision supplementing the gold clause."59 Since the debtor had to be pre-

53. 307 U.S. 247 (1935).

54. Id. at 257-58.

55. See also text at note 38 supra.

56. Mr. Justice Stone was joined in this dissent by three others, including Mr. Chief Justice Hughes, the author of the majority opinion in Norman, who also considered the situations to be different.

57. 307 U.S. at 261 (dissenting opinion). No mention whatever was made of multiple currency obligations in the congressional debate. See Dach, Validity of Price-Index Clauses Under the Gold Coin Joint Resolution, 13 GEo. WASH. L. REv. 328, 341 (1945).

58. "To be sure the statute has been expanded to the breaking point [footnote citation to the Guaranty Trust case] by the courts but so far the decisions have always been hinged on a hook, however frail, in the phrasing of the Joint Resolution." MONEY IN TEE LAW 307.

59. 307 U.S. at 257 (emphasis added). The entire plan of the parties then was characterized by the Court as "designed to pay 1912 gold dollars or fixed amounts of foreign currencies which were exact equivalents." This statement, however, would be true only at the time the agreement was made; thereafter, there would be no necessary correlation, since the value of each of the foreign currencies might fluctuate independently of the value of the gold dollar.

Perhaps the major purpose of the provisions for flexibility in the SACOR bond units, as discussed in text at note 19 supra, was to remove them from the category of being measured strictly by reference to gold, but whether this change is sufficient to allow a different judicial response is not clear. See generally CoLIIN, THE USE OF a CuRRENCY of AcCoUnt IN INTERNATIONal Loans 19-21 (1958); Delaume, supra note 11, at 215-16. 
pared at all times to pay in United States currency, the Court regarded the entire provision listing the currency alternatives as a single obligation "payable" in United States currency, ${ }^{60}$ hence entirely invalid. The dissent attacked this construction, arguing that the majority's reasoning led to:

[T] he extraordinary conclusion that a promise to pay foreign currency is void if expressed in an instrument containing an alternative promise to pay in money of the United States whether of gold standard or not. ${ }^{\text {B1 }}$

Despite the use of broad debtor-protection language by the majority, it was never contended that the Resolution was intended to cover even all debtors directly affected by the monetary crisis and reaction of the nineteen-thirties. Those persons, for instance, whose obligations were stated in foreign currencies were not relieved of the necessity of purchasing the foreign exchange with a larger number of devalued dollars. ${ }^{62}$ No "hook, however frail,"63 could be found in the language of the Joint Resolution to bring its provisions to bear. Although in Guaranty the Court refused to treat the multiple currency clause as distinct from, and independent of, the gold clause, the facts of that case,

60. 307 U.S. at 256. This theory may be compared with the view that the contract was not "payable" in United States currency because the debtor could not have discharged his obligation by tendering dollars at any time, either before the creditor's election or after he had selected another currency. Under general contract law applicable to optional provisions, the latter theory is probably more sound.

61. 307 U.S. at 264 (dissenting opinion). It is not entirely clear whether Mr. Justice Stone was referring to the particular case before the Court, in which case he was following the approach indicated at note 60 supra, or whether he was postulating the effect on future multiple currency clauses with the dollar option stated in terms of legal tender rather than gold coin. Without the reference to gold in a contract today, it is possible that this latter approach would not prevail, despite the broad language of the majority opinion in Guaranty Trust. The words of the Joint Resolution do not necessarily require that all obligations payable in United States money fall within its terms. Certainly the House Report that accompanied the Resolution indicated no more than that gold clauses were to be struck:

The resolution accomplishes three purposes:

(1) It declares that the clauses in public and private obligations stating that they are payable in gold or a specific coin or currency are contrary to public policy; (2) It provides that obligations, public and private, expressed to be payable in gold or in a specific coin or currency, may be discharged dollar for dollar in legal tender .... [(3) not relevant here.]

H.R. ReP. No. 169, 73d Cong., 1st Sess. 1 (1933). Some commentators have contended that the second sentence of clause (a) of the Resolution, which states that "Every obligation [payable in money of the United States] . . . shall be discharged upon payment dollar for dollar in any ... legal tender," does not constitute an extension of the preceding sentence's prohibition to provisions other than gold, as the majority in Guaranty seemed to indicate, but rather provides an explanation of what should be done with every such gold obligation. The second sentence, in this view, was added to avoid the possibility that the entire obligation would be considered void. Dach, supra note 57, at 332-34.

62. See Mr. Justice Stone's unchallenged statement in Guaranty Trust Co. v. Henwood, 307 U.S. 247, 261 (1939) (dissenting opinion); notes $84-89$ infra.

63. Note 58 supra. 
where both parties were American, presented a poor example of the usefulness and necessity of alternate payment provisions in international investment contracts. In fact, language in the opinion indicates that the focus of the decision was on wholly domestic money obligations:

The comprehensive language of the Resolution was intended ... to close "legal loopholes" contributing to "dislocation of the domestic economy ...." Here, the admitted purpose of the multiple currency provision supplementing the gold clause was ... to afford creditors of United States debtors on domestic money obligations contractual protection against possible depreciation of United States money. ${ }^{64}$

The dissent, discussing the ultimate implications of the majority opinion, argued that clearer language should be required before imputing to Congress an intention to go beyond considerations of the domestic economy "to end all possibility of creating an international market for bonds payable in dollars or alternatively abroad in foreign currencies, both without gold value."

A foreign bondholder, but not an international loan-since his bonds were originally floated in the United States-was involved in Bethlehem Steel Co. v. Zurich Gen'l Acc. \& Liab. Ins. Co ${ }^{60}$ The case demonstrates a failure by the Court to appreciate the possible distinctions between situations in which maintenance-of-value clauses are employed. As the issue was framed by the parties, the defendant steel company, apparently believing that the Resolution did not extend to foreign residents who had purchased bonds abroad at the time of original issue, sought application of the invalidating statute only to obligations initially purchased or presently held by residents of the United States. ${ }^{07}$ Acknowledging that the purpose of providing for payment of interest and principal of such bonds in foreign currencies was to facilitate their distribution in the respective markets, the borrower had clearly expressed an intention to perform its obligation to bona fide foreign holders by paying in

64. 307 U.S. at 257.

65. Id. at 264 (dissenting opinion).

66. 307 U.S. 265 (1939). The foreign bondholder in this case had purchased the bonds after the effective date of the Resolution, and not from the issuer but from American nationals who had bought them originally from domestic corporations.

67. In support of its motion for summary judgment, defendant bond-issuer Bethlehem Steel Co. appended a letter from its treasurer, as published by the New York Stock Exchange Bulletin, Jan. 13, 1934, which read, in pertinent part:

Assuming this Resolution to be applicable to the above-mentioned Bonds, we must regard it as binding upon and the public policy thereby declared applicable to, all residents of the United States, including this Company.

Accordingly, we have paid and shall continue to pay, in accordance with their terms, matured coupons from the above-mentioned Bonds, owned by residents of the United States, in lawful money of the United States . . ; ; but the above-mentioned Resolution continuing in effect, we shall deem it our duty to decline to make payment in foreign countries of such coupons to residents of the United States in gold or in any foreign currency ....

Record, p. 27, Bethlehem Steel Co. v. Zurich Gen'1 Acc. \& Liab. Ins. Co., supra note 66. 
the currency and in the amount specified in the multi-currency clause. ${ }^{68}$ Thus, payment had been refused only where the obligee refused to submit an affidavit stating that he had purchased the bonds as a foreign resident or where bonds purchased in this country had been resold abroad to avoid the application of the Joint Resolution. ${ }^{69}$ Although these facts were presented to the Court, no mention of them was made in its brief opinion, which held merely that present foreign ownership did not remove the holders from the operation of the Resolution. ${ }^{70}$ In using language broader than necessary to decide this particular case, ${ }^{71}$ the Court clouded the issue of whether a distinction may be drawn between domestic and international borrowing obligations. Despite the fact that Bethlehem has been construed as foreclosing the possibility of enforcing maintenance-of-value provisions in any case, ${ }^{72}$ it is important to note that the decision was made "under the governing principles announced in [Guaranty Trust]."73 In view of the original formulation of those principles in the context of wholly domestic money obligations, these two cases can fairly be said not to be "governing" in any bona fide international investment case which the Supreme Court is asked to decide.

From the standpoint of economic policy, the distinction between domestic and foreign obligations is sound. In the case of domestic transactions, a single

68. The apparent purpose of providing for payment of the interest on and the principal of such Bonds in foreign countries was to facilitate their sale and distribution in such countries by enabling residents of such countries who might purchase any of such bonds to collect such interest and principal at the respective maturity dates in such countries and in the currencies of such countries in specified amounts. In accordance with such purpose, we made or will make provision whereby owners of such Bonds residing in foreign countries, upon presentation and surrender of the coupons appurtenant thereto for the purpose, have received or may receive payment thereof in such countries and in the currencies of such countries in the amount specified in such coupons for such countries.

$I d$. at 26-27.

69. See the amended answer of the defendant Bethlehem Steel Co., id., at 17.

70. 307 U.S. 265 (1939).

71. For example, "Congress has, as it constitutionally may, provide that multiple currency provisions of dollar obligations are against public policy here and, thus, unenforceable." 307 U.S. at 267. "Courts in this country, State and Federal, can no longer enforce the contractual provisions which respondents have proceeded on, irrespective of their place of making." Ibid.

72. In view of the facts in the Bethlehem case, the statement by Professor Nussbaum that "the corporations, with no break-up of the loans, finally obtained much more than they had originally aspired because the multiple currency clause in its entirety was deemed to be an invalid gold clause," implies a belief that all such provisions were invalidated by the Supreme Court, because the corporations were seeking application of the Joint Resolution to the particular bondholders at bar and received same. MONEY IN THE LAW 393; but cf. note 61 supra. In Holyoke Water Power Co. v. American Writing Paper Co., 300 U.S. 324, 335 (1937), however, the Supreme Court acknowledged that application of the Joint Resolution might vary with the circumstances surrounding execution of the contract: "We must consider the situation of the parties, their business needs and expectations, in gauging their intention."

73. Bethlehem Steel Co. v. Zurich Gen'l Acc. \& Liab. Ins. Co., 307 U.S. 265, 267 (1939). 
standard of value, based upon the same currency, prevails between debtor and creditor. Although the creditor may suffer as a result of any inflation or unofficial currency depreciation, the legislature's action in devaluing the currency in relation to the other currencies of the world does not affect the amount of domestic purchasing power the debtor must repay. ${ }^{74}$ In other words, devaluation of the common currency does not injure either domestic party, while enforcement of the gold clause would enable the creditor to receive a greater number of dollars than he had lent and would impose a corresponding burden on the debtor, solely because of the official response to a national monetary crisis. ${ }^{75}$ The primary justification given for Congress' prohibiting gold value clauses as well as gold coin clauses was the elimination of a dual standard for the gold value of dollars, ${ }^{76}$ thus assuring uniformity of domestic currency:

The devaluation of the dollar placed the domestic economy upon a new basis. In the currency as thus provided, states and municipalities must receive their taxes; railroads, their rates and fares; public utilities, their charges for services. The income out of which they must meet their obligations is determined by the new standard. Yet, according to the contentions before us, while that income is thus controlled by law, their indebtedness on their "gold bonds" must be met by an amount of currency determined by their former gold standard. Their receipts, in this view, would be fixed on one basis; their interest charges, and the principal of their obligations, on another. ${ }^{77}$

On the other hand, when the transaction is between parties in different countries, the currency in which the obligation is expressed will be "foreign" to at least one of them, ${ }^{78}$ and either the creditor or the debtor must bear the

74. See note 9 supra for distinction between depreciation and devaluation. The immediate effect of devaluation is a revaluation upwards of imports and exports in the country's own currency because of the higher price paid for the foreign exchange. Exclusive of the effect this will have upon import and export industries, whose earnings will tend to fall or rise respectively, any secondary impact will depend upon income-level considerations. Only if there is already full employment in the economy will the increased demand for importsubstitution goods result in inflationary pressures. See ScHeicING, INTERNational EcoNomics 266-67 (1958).

75. Money in the Law 285.

76. Thus the title of the Joint Resolution is "To assure uniform value to the coins and currencies of the United States," and the preamble refers to "the declared policy of the Congress to maintain at all times the equal power of every dollar, coined or issued by the United States, in the markets and in the payment of debts." Note 34 supra. But see MoNEY IN the Law 285; Nussbaum, Comparative and International Aspects of American Gold Clause Abrogation, 44 YaLE L.J. 53, 58 (1934); Dawson, The Gold Clause Decisions, 33 Mice. L. Rev. 647, 668-75 (1935).

77. Norman v. Baltimore \& O. R.R., 294 U.S. 240, 315 (1935). See Holyoke Water Power Co. v. American Writing Paper Co., 300 U.S. 324, 341 (1937) (lease requiring repayment in gold measured by gold dollar held dischargeable dollar for dollar in current legal tender, to avoid injuring debtor by requiring that receipts and disbursements be made on different standards).

78. They may also, of course, employ yet another currency than that of either party, in which case the standard will be "foreign" to both parties. 
risk of devaluation of the repayment currency. Thus, there can be no attempt by Congress to assure a single standard of value between borrower and lender because there already exists more than one standard by the very nature of the binational transaction, which makes the parties vulnerable to the exercise of either government's currency valuation powers. ${ }^{79}$ If gold or some other additional standard is added to domestic contracts, the creditor is given a right to receive money representing greater domestic purchasing power after the official devaluation than he would have received before the devaluation. ${ }^{80}$ This amounts to a virtual creation of a monetary risk. In international obligations, however, maintenance-of-value provisions allow allocation of the existing risk necessarily involved. A decision whether to insert a stability clause in an international obligation is, in effect, a determination of which party will pay the cost arising from the action of either government in altering the value of the repayment currency in relation to the currency of the other country.

Provisions which include among the referents of value currencies other than those of the borrower's or the lender's country do not represent the unnecessary creation of another standard, because the parties to international investment may reasonably be expected to be concerned with standards of value other than specific currencies. The investor, for example, is less interested in the value of the obligation in "his own currency" than he is in preserving its value for purposes of reinvestment ${ }^{81}$ that may be in a different currency.

79. Because the exchange rate is a ratio between currencies of different countries, the devaluation or revaluation of any one currency is simultaneously and automatically a revaluation or devaluation respectively of the other currencies, although the terms "revalued" and "devalued" by common usage are applied to the currency of the country which has taken the initiative in altering the relationship. International obligations will be affected regardless of which government takes official action and which remains passive. ScHeLrivg, op. cit. supra note 74, at 82 . For an example of a situation in which Congress did take account of the loss of purchasing power to recipients of dollar amounts following United States devaluation, see "An act to authorize annual appropriations to meet losses sustained by officers and employees of the United States in foreign countries due to appreciation of foreign currencies in their relation to the American dollar . . . "48 Stat. 466 (1934), and congressional discussion at 78 CoNG. REc. 3012-3026 (1934).

80. The amount received may or may not have any correlation with the actual economic position of the parties due to inflation. If devaluation occurs as the culmination of a period of depreciating currency value (inflating prices), the presence of a protective clause may only partly compensate or may over compensate the creditor for loss in purchasing power relative to the time of the loan. Only fortuitously would the increased number of currency units to be paid because of the clause equal the loss in purchasing power of the number of units originally loaned (the amount repayable if no clause were included). Because it is only the official action itself which triggers the increase in number of units to be received, a lender might profit to the full extent of the amount of devaluation in the case of a loan made immediately before devaluation. He would thus receive $\$ 125$ for $\$ 100$ invested just before a devaluation of $20 \%$, irrespective of whether depreciation should occur after the loan is made.

81. It is only at the time the investor wishes to "consume" part of his principal or profit that the value in a particular currency is relevant. The situation is conceptually related to the justification given for tax-free transfers of certain assets, INT. REV. CODE OF 1954, § 1031, 
Likewise, the international borrower is not so dependent on the fortunes of the currency of one country, because borrowers most willing to assume foreign currency debts are those who seek funds for use in industries which operate internationally; such parties realize an appreciation in their nominal income when their own currency devalues. Prices set by the world market, for such commodities as wheat or oil as distinguished from such local items as haircuts or ice cream, will translate into larger amounts in the seller's currency, since the foreign exchange received has been revalued in relation thereto. ${ }^{82}$ Alternatively, where the market price is not so established, the seller will profit from the increased number of sales which result from the fact that the price he must receive domestically is now less expensive in terms of the foreign currency of buyers. ${ }^{83}$

The Joint Resolution, although it restricts the usefulness of multiple currency provisions in international transactions, does not afford prospective protection to foreign and domestic debtors in such transactions, since it is readily avoidable by proper framing of the contract. ${ }^{84}$ Because the application of the Resolution is limited to debts payable in money of the United States, neither the simple foreign currency clause, nor even a multiple currency option or unitacct provision involving a number of currencies other than dollars, is prohibited. ${ }^{85}$ At present, investors of dollars legally may require repayment in foreign currency or legally may require repayment in dollars; inclusion of

and for proposals to exempt all reinvested capital funds from income taxation on a "rollover" principle so as to preserve the original value of the investment until final realization. See New York Stock Exchange, Taxes-Equity Capital-and Our Economic Chailenges 3S-40 (1953), reprinted in Bittker, Feneral Income Estate and Gift Taxation 379-80 (1958 ed.). See also Clark, An Alternative to Capital Gains Taxation: A "RollOver" Account for Investment Assets, 4 How. L.J. 157, 161 (1958).

82. See Kindleberger, International Economics 71 (1953); Schelling, op. cit. supra note 74, at 266-68; Colnrw, op. cit. supra note 59, at 21. Contra, Brief for Petitioner, pp. 44-45, Bethlehem Steel Co. v. Zurich Gen'l Acc. \& Liab. Ins. Co., 307 U.S. 265 (1939).

83. See KINDLEBERGER, op. cit. supra note 82 , at 71. The result in this case also depends upon the output of the devaluing country not being large enough to bring down the world price by virtue of its underselling the rest of the market.

An additional protection for a large corporation with an international business is the likelihood that it will have holdings of foreign exchange at the time of devaluation, and thus receive the benefit of any increase in value. Supp. Brief for Respondent, p. 7, Bethlehem Steel Co. v. Zurich Gen'l Acc. \& Liab. Ins. Co., supra note 82.

84. One law journal article contemporaneous with the enactment of the Joint Resolution correctly predicted that the invalidation of gold clauses would be apt to stimulate the development of new devices, such as commodity and index clauses, for accomplishing the same purposes. Dawson, The Gold Clause Decisions, 33 MrcH. L. REv. 647, 677-84 (1935).

85. See Money in the Law 433; Mann, Legal. Aspect of Money 156-57 n.5 (1953 ed.). This result obtains despite the fact that all judgments in American courts must be stated in terms of United States currency, even in cases involving obligations in foreign money. See Fraenkel, Foreign Moneys in Domestic Courts, 35 CoLUM. L. REv. 360 (1935). To consider such obligations "payable in money of the United States" within the terms of the Joint Resolution would mean that every obligation was so payable, whether the contract be to deliver a horse, a week's work, or fifty francs, because damages if awarded would 
a dollar repayment provision in conjunction with other currencies, however, will nullify all other previously enforceable payment provisions. ${ }^{86}$ Furthermore, the limitation of the Resolution to obligations in gold or money measured thereby has been uniformly thought to exempt obligations using as the referent of money value a basic commodity such as wheat ${ }^{87}$ or an index clause based on the value of a range of products. 88 To the extent that any of these devices is permitted, the burden on United States debtors in case of dollar devaluation will be fully as great as it would be with multiple currency or unitacct obligations which include the dollar as a repayment medium. ${ }^{89}$ These anomalies which result from applying the Joint Resolution to intercurrency obligations demonstrate that Congress was not concerned with tying parties in different countries to the standard of the dollar alone, and cast doubt upon the validity of the "public policy" involved in denying effect to value clauses in international

be in terms of dollars. See Dach, stipra note 57 , at $335 \mathrm{n} .15$; Stone, J., dissenting in Guaranty Trust Co. v. Henwood, 307 U.S. 247, 260 (1939).

The Joint Resolution was held not to apply to bonds providing payment in English pounds or Canadian dollars or Swiss francs or Belgian francs or German marks, despite the fact that the bonds themselves purported to be "fifty year gold bonds," in English Transcontinental, Ltd. v. Puebla Tramway, Light \& Power Co., 186 Misc. 481, 61 N.Y.S.2d 356 (Sup. Ct. 1946). No other case has arisen in which the argument has been presented.

86. Ordinary foreign currency debts were never subjected to the Joint Resolution. Consequently, an American obligated in terms of guilders had to disburse guilders without ado; only the additional privileges which the multiple currency clause conferred upon the creditor destroyed, according to the court, his right to guilders-a perplexing result.

Money IN the LaW 435. See ManN, supra note 85, at 156-57 n.5.

87. Obligations of the "wheat futures" variety may or may not be related to actual commerce in wheat. Speculation in foreign-exchange and commodities, indeed, is considered desirable because of its tendency to cushion market fluctuations. See ScrenLnNG, op. cit. supra note 74, at 86-98. Cf. Mr. Justice Stone's less optimistic prediction regarding the validity of contracts expressed in optional terms. Guaranty Trust Co. v. Henwood, 307 U.S. 247, 264 (1939) (dissenting opinion).

88. At the stage of final "realization" of invested funds, in fact, such a purchasingpower referent of value might well be more pertinent than the currency-purchasing referent which would best suit the purposes of the international investor at the earlier stage of shifting among investment opportunities. See text at note 81 supra. Apparently administrative difficulties or problems arising from long-term prediction of relevant items to include in the list have prevented the use of index clauses in bonds, although they have become common in labor wage contracts. The much-quoted single instance of bonds employing this device was not of sufficient extent or duration to permit a valid evaluation of their success. See Dach, stpra note 57, at 328 n.1.

89. See the comments of Mr. Justice Stone in dissent in Guaranty:

When the Joint Resolution was adopted there were many obligations of American citizens payable abroad exclusively in foreign currency, and the attendant devaluation of the dollar greatly increased the burden of performance of such contracts through the necessity of purchasing with depreciated dollars the foreign exchange required for their fulfillment.

307 U.S. at 261 (dissenting opinion). 
obligations. ${ }^{20}$ Protection is not afforded the debtor seeking to borrow available foreign funds, since in order to obtain the loan he may, in any event, have to agree to pay the lenders in each country in the currency of that respective country, or at the investors' option, even in one of a number of currencies other than the dollar. Moreover, such protection seems unnecessary, for borrowers wishing to float bonds on the international market are aware of the risk of currency changes, and the unitacct provision merely facilitates an explicit definition and an assumption of that risk. ${ }^{21}$ The practical effect of refusal to enforce optional currency provisions if the dollar is included as a repayment medium is to restrict the possibility of floating a single bond issue simultaneously in the United States and other countries, thereby depriving the borrower of the opportunity to include the United States capital market in a multilateral borrowing transaction. Thus future bond issues of the SACOR type are unlikely to include the dollar among the repayment currencies. Despite the provisions for fluctuation of the unit in the event that every one of the stated currencies is altered in value, the unitacct nonetheless requires payment, not in gold, but "in an amount in money of the United States measured thereby." The risk of nonenforcement in United States courts, therefore, would be too great for an investor to take..$^{22}$

Consideration of the importance of freer international flow of investment funds, independent of considerations controlling as to domestic obligations, should be the relevant factor in a decision respecting the desirability of enforcing unitacct provisions. National as well as individual fears arising from experience during the almost complete collapse of international investment in the 1930's ${ }^{93}$

90. By way of comparison:

[A] law of the United States Military Government of the German occupation zone ... expressly invalidate[d] all "stabilizing clauses," including clauses correlating the mark to a "sliding scale or in any other way to the prices of fine gold ... or to the price of other precious metals, merchandise, securities or currencies other than German.... Money in the Law 307 (emphasis added).

91. Compare text at notes 51-52 sitpra.

92. But see note 59 supra for views of proponents of unit account provisions. See also the discussion of a recent Republic of Austria bond issue containing the United States dollar as one of the optional currencies, Delaume, Gold and Currency Clanses in Contemporary International Loans, 9 AMr. J. Coxrp. L. 199, 214 (1960).

In view of the highly controversial character of American judicial decisions invalidating multiple currency clauses, and of the strong opposition and criticism to which these decisions have been subjected, this courageous attempt to reintroduce such clauses in American practice is to be welcomed ....

Ibid. (footnotes omitted).

The position taken by one writer with regard to index clauses-that they should be included even if there is a possiblity of nonenforcement because the contract will then simply be enforced as if it contained no such clause-fails to take account of the fact that the investor does not obtain the inclusion of these protective clauses at no cost; concessions will have been made in the interest rate or other terms at no added benefit to the investor. See Dach, supra note 57 , at 343-44.

93. See Ellsworth, The Internationai Economy 375-88 (1958 ed.); Carroli, Private Investments Abroad 12-13 (1954). 
are now being overcome by recognition of the benefits to be afforded..$^{04}$ Whereas sentiment at the time the Joint Resolution was enacted might have demanded a severing of economic ties with other depressed countries in an attempt to deal with unemployment and other economic problems country by country, governments today actively seek to promote the interlacing of economies. For this reason, contemporary application of legislation striking maintenance-ofvalue clauses designed to facilitate international transactions would be anachronistic. Indeed, recent revived interest in foreign portfolio investment has been both accompanied and influenced by official encouragement. The United States has been among the leaders in the movement toward free convertibility of currencies, increased international trade in goods and services, and the development of regional free trade areas such as the European Economic Community. ${ }^{96}$ Programs designed to protect an encourage private foreign investment have been especially prominent in discussion and implementation of foreign policy objectives. ${ }^{97}$ Through treaty negotiations, the United States has sought the furtherance of its longstanding principles favoring foreign investment. $^{98}$ The protection of such investment constitutes the subject matter of over half of each new commercial treaty concluded, ${ }^{99}$ though the particular multiple currency problems raised by the Joint Resolution have not been treated.

94. See Committee for Econonic Developnent, The International Positron of the Dollar 42 (1961) ; U.N. Dep't of Economic and Soctal Affatrs, The International Flow of PrIvate Capital 1956-1958, at 50 (U.N. Pub. Sales No. 59. II.D.2, 1959). "Portfolio investments, which had declined greatly after 1930, when they were the major form of international investment, have, of late, regained momentum. This change may be due in part to the effect of the recession on long-term interest rates...." Id. at 9-10.

95. See Buchanan \& Lutz, Rebuilding the Wordd Econony 33-37 (1947) ; ScheliING, op. cit. supra note 74, at 105; ElLsWORTE, op. cit. supra note 93, at 389; WoRLD COMarunity Assoc. of Yale Law School, Legal Problems in International Trade and INVESTMENT 46-47 (1962).

96. See, e.g., Schelling, op. cit. supra note 74, at 366-69; Dillon, United States Forcign Trade and Investment Policies, in Legal Problems of International Trade 107 (Proehl ed. 1959). See generally U.S. Dep't of Commerce, Reprint from Foreign Commerce Weekly of Oct. 31, Nov. 7, Nov. 14, 1960. Futhermore, deviation from our basic policy of allowing the greatest freedom of choice to private traders and investors, after having taken the lead in the multilateralization of activities in the postwar world, might lead to reciprocal action by other countries and result in decreased benefits to all parties. CoMmrrTEE FOR Economic Development, op. cit. supra note 94, at 51-52.

97. See generally Brainard, International Economics and Public Policy 525673 (1954).

[A] major motivating force behind our [United States] foreign economic policy is the deep and abiding conviction that government and intergovernment measures are no substitute for the vitality and initiative of private investment. The goal of our official investment program is to help create an international climate in which private enterprise can expand and prosper in the more developed nations and take root and flourish in the less developed areas.

Beale, Government Efforts To Increase Private Investment Abroad, 39 Dep't State BuLl. 967 (1958). But cf., Managensent Guide to Overseas Operations 227-28 (Fenn ed. 1957).

98. See Walker, Treaties for Encouragement and Protection of Foreign Investncut: Present United States Practice, 5 AN. J. Cosp. L. 229 (1956).

99. Id. at 234 . 
Although a treaty provision might insure the enforcement of unitacct bonds, ${ }^{100}$ clarification of the status of maintenance-of-value clauses of all types could be most effectively accomplished by means of congressional action. An evaluation of the general policy, as enacted and as interpreted, would permit focusing upon the real distinctions between domestic and foreign transactions. $^{101}$ The burden upon debtors under gold value and multiple currency obligations in the nineteen-thirties was greater in many other countries than in the United States, ${ }^{102}$ but the official response generally was invalidation of protective clauses in existing contracts only. ${ }^{103}$ Even if the applicability of the Joint Resolution be retained with regard to domestic obligations, protective clauses should be allowed in the area of foreign trade and investment, where there is a legitimate need to provide for exchange rate fluctuations. ${ }^{104}$ The restrictions upon international investment which arise from the emergency legislation of the nineteen-thirties appear to have unanticipated or unintended by Congress even at that time. ${ }^{105}$ Re-evaluation of what the courts have interpreted to be basic United States policy is all the more necessary thirty years later, when protection and encouragement of such international cooperation is postulated as a desirable means of achieving economic and political goals.

100. Judicial recognition of the foreign relations aspect of protective clauses in international investments is indicated in Bethlehem Steel Co. v. Zurich Gen'l Acc. \& Liab. Ins. Co., 307 U.S. 265 (1939). The Supreme Court held that the Joint Resolution was applicable to bonds held by the foreign creditor "in the absence of any claim of international rights based upon the treaty provisions of the Constitution," id. at 267, implying that executive action to encourage foreign investment could include endorsement of protective clauses and that such action would result in judicial enforcement of the clauses.

101. See text at notes 74-83 supra.

102. Even the effect of the United States Joint Resolution was to benefit more nonAmericans owing gold dollar debts to American creditors than Americans owing such debts to nonresidents. See MONEY IN THE LAW 433-34. In the House of Representatives the bill was attacked as having been "framed and brought here in the interests of the foreign debtors of the United States." 77 CoNG. REC. 4538 (1933) (remarks of Rep. McFadden).

103. See MONEy IN THE LAw 293-96. A list of the relevant foreign statutes appears $i d$. at $280-81$ n.5.

104. One change might take the form of a simple deletion from 31 U.S.C. $\S 463$ (a) of the phrase "or in an amount in money of the United States measured thereby," leaving intact the prohibition against gold coin and gold bullion obligations as complementing the removal of gold from circulation. If it were thought desirable to limit judicial discretion by sanctioning such agreements only in the area of foreign trade or investment, however, the present language might be so modified. In such event, the qualifying phrase should be clearly linked only to the latter type provision mentioned in the statute, to avoid confusion regarding gold coin clauses. Thus the prohibition would include provisions for "payment in gold ... or, cxcept in cases of international trade or investment obligations, in an amount in money of the United States measured thereby." Alternatively, specific provision might be made that the prohibitions should not apply to obligations in international trade or investment stated in terms of multiple currency clauses or units of account.

105. Admittedly the scope of the Joint Resolution was not limited to domestic obligations to pay gold or gold value, but no clear language is present to indicate that other types of international protective clauses should be invalidated. See remarks by Mr. Justice Stone in Guaranty Trust Co. v. Henwood, 307 U.S. 247, 264 (1939) (dissenting opinion). 